\title{
Ethanolic Extract of Ocimum Gratissimum (Scent Leaf) Leaves Improves Haematological Parameters in Restrain-Stressed Rats
}

\section{1*ANACHUNA, KK; ${ }^{2}$ MOKE, EG; ${ }^{3}$ OYEM, JC; ${ }^{2}$ OMOGBIYA, AI; DAUBRY, ${ }^{1}$ TME; ${ }^{1}$ EBUWA, EI}

\author{
${ }^{*}$ Department of Human Physiology, Faculty of Basic Medical Sciences, Delta State University Abraka, Delta State, Nigeria. \\ ${ }^{2}$ Department of Pharmacology and Therapeutics, Faculty of Basic Medical Sciences, Delta State University Abraka, Delta State, Nigeria. \\ ${ }^{3}$ Department of Human Anatomy and Cell Biology, Faculty of Basic Medical Sciences, University of Port Harcourt, Port Harcourt, Nigeria. \\ *Corresponding Author Email: goldasaba20@gmail.com, Tel: +2348060410865
}

\begin{abstract}
Stress alters system physiology as well as humoral immunity and hematology, and its problems have become a global issue. The present study was designed to investigate effects of the use of traditional herbs such as Ocimum gratissimum (OG) on hematological parameters in stressed rats. We subjected adult female Wistar rats to prolonged restrained stress for 14 days and administered $100 \mathrm{mg} / \mathrm{kg}, 200 \mathrm{mg} / \mathrm{kg}, 400 \mathrm{mg} / \mathrm{kg}$ of OG leaf extract and Vitamin C respectively for 14 days. Animals (200-250 g) were sacrificed by cervical dislocation at day 0, day 7 and Day 14 so as to assess the dose and time dependent effect of the extract. Findings revealed that OG leaf extract caused a dose-dependent significant protective effect $(\mathrm{P}<0.05)$ on the packed cell volume $(\mathrm{PCV})$, total white blood cell (WBC) count, haemoglobin (Hb), platelet count and total red blood cell (RBC) count compared to Vitamin C treated group. Our study confirms that OG leaf extract is better at improving haematological parameters of restrainstressed rats compared to Vitamin C and it was more effective in animals that were administered $100 \mathrm{mg} / \mathrm{kg}$ and 400 $\mathrm{mg} / \mathrm{kg}$ of the extract. The result indicates that OG leaf extract could alleviate prolonged exposure to stress by lowering PCV, total WBC, total RBC, hemoglobin count and elevating blood platelets.
\end{abstract}

\section{DOI:https://dx.doi.org/10.4314/jasem.v25i9.10}

Copyright: Copyright (ㅇ 2021 Anachuna et al. This is an open access article distributed under the Creative Commons Attribution License (CCL), which permits unrestricted use, distribution, and reproduction in any medium, provided the original work is properly cited.

Dates: Received: 09 May 2021; Revised: 12 August 2021; Accepted: 12 September 2021

Keywords: Ocimum gratissimum, total WBC, vitamin C, haematology

Stress is a prime signal that re-orders homeostasis by continually interrupting the body's physiology (Bhattacharya and Ghosal, 2000). Several stress agents otherwise known as stressors trigger a "crisismode" physiological response, which the body attempts to return to homeostasis by means of an adaptive response (Calabrese et al., 2007). Stress and its associated pathologies account for over $70 \%$ of illness globally (Bamidele et al., 2020). Prolonged restrained stress (freedom barred stress) may lead to long-term pathologies of the cardiovascular system. Such stressors have the ability to disrupts the reproductive system as well as the normal function of hypothalamus pituitary- endocrine glands axes thus leading to changes in the levels of hormones (O'Connor et al., 2020). Another form of stress called the "immobilization stress" enhances Nitric oxide synthase activity that led to alterations in levels of plasma as well as changes in human body physiology (Yaribeygi et al., 2017). Aversive stimulus may result to motivation and improved task performance whereas distressing stimulus leads to anxiety, depression, social dysfunction and intentions of suicide (Bamidele et al., 2020). Birben et al. (2012) reported that stress increases the production of reactive oxygen species (ROS) and depletion of the antioxidant defense system associated with lipid peroxidation. However, Ramadan and Alshamrani (2015) demonstrated that stress disrupts haematological parameters in rats. Another study reported that stress alters the well-being of air breathing loaches by altering their hematological parameters (Kandeepan, 2014). To date, naturally occurring biological active constituents of several plants is used in traditional medicine due to their availability and low cost. This has led to a rapid increase in the use of these herbal remedies especially in the management of different diseases with several of them incorporated into orthodox medicine (Ekor, 2014; Erhirhie et al., 2015; Anachuna et al., 2018; Moke et al., 2019; Bamidele et al., 2020). The effect of herbal medicine on haematology have been reported in recent times (Emudainohwo et al., 2015; Ladokun et al., 2015; Moke et al., 2018). Demand of plants containing essential oil in orthodox medicine is on the increase (Ueno et al., 2019). One of such plants is Ocimum gratissimum (OG). It is a perennial 
herbaceous plant cultivated in Nigeria due to its culinary and medicinal importance (Aguiyi et al., 2000; Ofem et al., 2012; Shittu et al., 2016). Ijeh et al. (2004) demonstrated the presence of alkaloids, tannins, flavonoids, phytates, and oligosaccharides on phytochemical screening of OG. Its essential oil contains eugenol as one of its active ingredients and it was demonstrated to possess antibacterial activities (Ayinla et al., 2011; Omodamiro and Jimoh, 2015). A study by Shittu et al. (2016) reported that OG administration improved blood parameters in diabetes mellitus experimental animal models. Studies by Ayinla et al., (2011) and Chao et al., (2016) revealed that OG consumption causes marked hypolipidaemic effect. Many synthetic drugs such as amphetamine, benzodiazepines, caffeine and anabolic steroids have been applied in the management of stress. A rise in the use of herbal medicine in developing regions have been reported (WHO, 2013; Ekor, 2014; Moke et al., 2021). Sarjan et al. (2017) demonstrated a highly significant result on the use of an herbal extract on chronic stress induced immunodeficiency in rats. Owing to the numerous reported medicinal benefits of $\mathrm{OG}$, the present study was designed to investigate the effect of ethanolic extract OG on haematological indices in stress-induced male Wistar rats.

\section{MATERIALS AND METHODS}

Experimental animals: Thirty female Wistar rats, weighing between $200-250 \mathrm{~g}$ were purchased and housed in the animal house of College of Health Sciences, Delta State University Abraka, Nigeria. Animals were housed in propylene cages to allow adequate ventilation and their cages were cleaned daily. They were maintained under standard room temperature and $12 \mathrm{~h}$ light/dark cycle. The animals were acclimated for seven days and were provided with standard pellet diet and water given ad libitum. All experimental protocols were conducted according to the guiding principles of the Research Ethics on the Use of Laboratory Animals of the Delta State University Abraka with reference number (REC/FBMS/DELSU/19/81) as recommended by the declaration of Helsinki and the Guiding principles in the care and use of animals.

Plant Materials: Fresh leaves of OG plants were obtained from a farmland in Abraka, Ethiope East Local Government of Delta State of Nigeria. The plant was authenticated, and identified by Dr. A.H. Erhenhi in the Herbarium Unit of the Botany Department of Delta State University, Abraka.

Plant extracts preparation: Fresh leaves of OG were washed in running tap water, air-dried for three days before it was ground into a powdered form. Thereafter,
$50 \mathrm{~g}$ of OG powder was soaked in $100 \mathrm{ml}$ of ethanol for $24 \mathrm{hrs}$. The concentrate was kept inside the heating mantle of the fume cupboard of the extracting machine to evaporate the ethanol and the final product, which was a semi-solid residue, was stored in the refrigerator. The dose of $\mathrm{OG}$ administered was adopted from Shittu et al. (2016).

Stress induction: Model of chronic stress induction was adopted from Gudipudi et al. (2015). The rats were placed in plastic tubes (inner diameter, $5.7 \mathrm{~cm}$; length, $20.3 \mathrm{~cm}$ ) fixed with adhesive tape on the outside. One end of the tube remained open to allow breathing. The tubes completely restricted lateral movement and front to back movement of the animals. Immediately the animal enters inside the tube, it is placed horizontally to make the animal uncomfortable. The animals were exposed to stress for one hour in the morning between 8:00 am and 11:00 am daily.

Experimental design: Experimental animals were grouped into six groups containing five rats per group. The groupings were as follows: Group 1 (Normal control): No stress induction and rats fed normal diet. Group 2 (Restrained stress control - RS control): Stress was induced by retraining the rats for one hour with rats fed normal diet. Group 3 (RS+100 mg/kg): Stress was induced by restraining the rats for an hour and treated with $100 \mathrm{mg} / \mathrm{kg} / \mathrm{bw}$. Group $4(\mathrm{RS}+200$ $\mathrm{mg} / \mathrm{kg}$ ) one hour restraint stress (RS) animals treated with $200 \mathrm{mg} / \mathrm{kg} / \mathrm{bw}$ of OG leaf extract. Group 5 (RS+400 mg/kg): contained RS animals treated with $400 \mathrm{mg} / \mathrm{kg} / \mathrm{bw}$ of OG leaf extract. Group 6 (standard group - RS+Vitamin C) one hour RS animals treated with $200 \mathrm{mg} / \mathrm{kg} / \mathrm{bw}$ of Vitamin C. Treatments were administered orally daily for 14 days.

Animal sacrifice and blood collection: Animals (two rats per group) were sacrificed randomly at Day 0, Day 7 and Day 14 respectively in other to assess the dose and time dependent effect of OG in attenuating stress. Animals were sacrificed by cervical dislocation and blood was collected from the vena cava into welllabeled EDTA bottles.

Haematological assessment: Total red blood cell (Total RBC) count, packed cell volume (PCV), total white blood cell (Total WBC) count, were assessed using the Hemocytometer method (Thrall et al., 2012). Hemoglobin $(\mathrm{Hb})$ concentration was measured using the Cyanmethemoglobin method of Higgins (Thrall et al., 2012).

Statistical Analysis: Data were subjected to Statistical Package for Social Sciences, version 23 (SPSS produced by SPSS Inc. Chicago), analyzed, and expressed as Mean \pm SEM (Standard Error of Mean). 
Statistical comparisons were performed by One Way Analysis of Variance (ANOVA) followed by Fisher's Least Significant Difference (LSD) multiple mean comparison analysis. $\mathrm{P}$ values of $<0.05$ were considered statistically significant.

\section{RESULTS AND DISCUSSION}

The effect of Ocimum gratissimum on haematological parameters of Wistar rats under restrained stress is shown in Tables 1-5. There was significant decrease $(\mathrm{P}<0.05)$ in the PCV level of experimental animals treated with $100 \mathrm{mg} / \mathrm{kg} / \mathrm{bw}$ and $400 \mathrm{mg} / \mathrm{kg} / \mathrm{bw}$ of OG for 7 days and in all treated groups administered varying doses of OG for 14 days when compared with normal and RS control groups. Maximal significant decrease in PCV was seen in experimental animals that were administered $400 \mathrm{mg} / \mathrm{kg} / \mathrm{bw}$ of OG. (Table 1). Table 2 shows significant decrease $(\mathrm{P}<0.05)$ in the hemoglobin level of RS experimental animals administered $100 \mathrm{mg} / \mathrm{kg} / \mathrm{bw}$ and $400 \mathrm{mg} / \mathrm{kg} / \mathrm{bw}$ of OG for 7 days when compared to the normal control and RS control. There was a non-significant decrease $(\mathrm{P}>0.05)$ in all RS experimental animals that received OG and vitamin $\mathrm{C}$ when compared with normal control and RS control groups. Highest significant decline in $\mathrm{Hb}$ level was obtained in $\mathrm{RS}$ animals administered $100 \mathrm{mg} / \mathrm{kg} / \mathrm{bw}$ of OG for 7 days. (Table
2). Restrained stress animals administered OG shows significant $(\mathrm{P}<0.05)$ decrease in total $\mathrm{RBC}$ in the experimental rats administered $100 \mathrm{mg} / \mathrm{kg} / \mathrm{bw}$ and 200 $\mathrm{mg} / \mathrm{kg} / \mathrm{bw}$ of OG for 7 days when compared with the normal and RS control groups. However, there is a non-significant $(\mathrm{P}>0.05)$ decrease in total $\mathrm{RBC}$ count following the administration of varying doses of $\mathrm{OG}$ and vitamin $\mathrm{C}$ for 14 days. (Table 3). Total WBC was decrease in the experimental animals treated with varying doses of OG for 7 and 14 days when compared with the normal and RS controls. Animals treated with vitamin $\mathrm{C}$ had a higher total WBC count as compared to the RS control.

However, no observations were significant. (Table 4). Seven (7) days treatment showed non-significant ( $\mathrm{P}>0.05)$ difference in $\mathrm{RS}$ rats administered vitamin $\mathrm{C}$ for 7days when compared with the normal and RS controls. Only RS animals that received $200 \mathrm{mg} / \mathrm{kg} / \mathrm{bw}$ of $\mathrm{OG}$ for 7 days showed a significant $(\mathrm{P}<0.05)$ decrease in the platelet compared to the normal control and RS groups. There was non-significant $(\mathrm{P}>0.05)$ increase in platelet count of RS experimental rats administered $\mathrm{OG}$ and vitamin $\mathrm{C}$ for 14 days. However, significant increase in platelet count was shown in RS animals that received $100 \mathrm{mg} / \mathrm{kg} / \mathrm{bw}$ of $\mathrm{OG}$ and vitamin $\mathrm{C}$ respectively for 7 days and in $\mathrm{RS}$ rats administered vitamin $\mathrm{C}$ for 14 days.

Table 1: Effect of Ocimum gratissimum on packed cell volume (\%) of Wistar rats under restrained stress

\begin{tabular}{llll}
\hline Groups & Day 0 & Day 7 & Day 14 \\
\hline Normal Control & $38.33 \pm 1.09$ & $43.00 \pm 2.15$ & $38.00 \pm 2.03$ \\
RS Control & $36.33 \pm 3.42$ & $37.00 \pm 1.14$ & $39.00 \pm 1.48$ \\
RS+100 mg/kg & $35.63 \pm 1.13$ & $29.33 \pm 2.17^{* \#}$ & $33.75 \pm 3.40^{* \#}$ \\
RS+200 mg/kg & $37.33 \pm 2.07$ & $38.25 \pm 3.10$ & $31.67 \pm 2.07^{* \#}$ \\
RS+400 mg/kg & $34.33 \pm 1.31$ & $26.00 \pm 2.12^{\text {*\# }}$ & $28.25 \pm 3.95^{\text {*\# }}$ \\
RS+Vitamin C & $38.33 \pm 2.09$ & $39.00 \pm 2.15$ & $34.50 \pm 2.03$ \\
\hline
\end{tabular}

All values are expressed as mean \pm standard error of mean $(S E M) ;{ }^{*}=P<0.05$ when compared with normal control; ${ }^{*}=P<0.05$ when compared with restrained stress $(R S)$ control.

Table 2: Effect of Ocimum gratissimum on hemoglobin $(\mathrm{Hb})$ concentration $(\mathrm{g} / \mathrm{dl})$ of Wistar rats under restrained stress

\begin{tabular}{llll}
\hline Groups & Day 0 & Day 7 & Day 14 \\
\hline Normal Control & $11.78 \pm 0.69$ & $14.33 \pm 1.15$ & $12.33 \pm 2.03$ \\
RS Control & $12.18 \pm 0.12$ & $14.83 \pm 0.14$ & $12.75 \pm 1.48$ \\
RS+100 mg/kg & $10.78 \pm 0.13$ & $7.56 \pm 0.17^{* \#}$ & $11.25 \pm 1.22$ \\
RS+200 mg/kg & $12.78 \pm 0.17$ & $12.75 \pm 1.10$ & $10.56 \pm 2.00$ \\
RS+400 mg/kg & $11.78 \pm 1.31$ & $8.66 \pm 0.12^{* \#}$ & $9.42 \pm 1.95$ \\
RS+Vitamin C & $12.48 \pm 0.09$ & $13.00 \pm 0.15$ & $11.75 \pm 1.56$ \\
\hline
\end{tabular}

All values are expressed as mean \pm standard error of mean (SEM); ${ }^{*}=P<0.05$ when compared with normal control; ${ }^{*}=P<0.05$ when compared with restrained stress $(R S)$ control.

Table 3: Effect of Ocimum gratissimum on total red blood cell count $\left(\times 10^{9} / \mathrm{L}\right)$ of Wistar rats under restrained stress

\begin{tabular}{llll}
\hline Groups & Day 0 & Day 7 & Day 14 \\
\hline Normal Control & $3.91 \pm 0.09$ & $4.18 \pm 0.15$ & $4.03 \pm 2.03$ \\
RS Control & $3.71 \pm 0.42$ & $4.67 \pm 0.14$ & $4.17 \pm 1.48$ \\
RS+100 mg/kg & $3.22 \pm 0.13$ & $3.44 \pm 0.17^{\text {*\# }}$ & $4.12 \pm 1.40$ \\
RS+200 mg/kg & $3.62 \pm 0.07$ & $3.47 \pm 0.10^{* \#}$ & $3.61 \pm 2.07$ \\
RS+400 mg/kg & $3.59 \pm 0.31$ & $3.83 \pm 0.12$ & $3.70 \pm 1.95$ \\
RS+Vitamin C & $3.91 \pm 0.09$ & $3.92 \pm 0.15$ & $3.95 \pm 2.03$ \\
\hline
\end{tabular}

All values are expressed as mean \pm standard error of mean $($ SEM $) ;{ }^{*}=P<0.05$ when compared with normal control; ${ }^{*}=P<0.05$ when compared with restrained stress $(R S)$ control. 
Table 4: Effect of Ocimum gratissimum on total white blood cell count $\left(\times 10^{9} / \mathrm{L}\right)$ of Wistar rats under restrained stress

\begin{tabular}{rllll}
\hline Groups & Day 0 & Day 7 & Day 14 \\
\cline { 2 - 5 } Normal Control & $8.27 \pm 1.12$ & $10.20 \pm 0.65$ & $10.80 \pm 1.33$ \\
RS Control & $8.07 \pm 0.12$ & $11.22 \pm 1.44$ & $11.70 \pm 1.28$ \\
RS $+100 \mathrm{mg} / \mathrm{kg}$ & $6.77 \pm 1.28$ & $8.26 \pm 2.17$ & $9.90 \pm 0.40$ \\
$\mathrm{RS}+200 \mathrm{mg} / \mathrm{kg}$ & $7.77 \pm 0.27$ & $9.30 \pm 0.30$ & $8.67 \pm 1.07$ \\
$\mathrm{RS}+400 \mathrm{mg} / \mathrm{kg}$ & $6.77 \pm 0.34$ & $9.20 \pm 1.32$ & $8.90 \pm 1.48$ \\
$\mathrm{RS}+\mathrm{Vitamin} \mathrm{C}$ & $8.04 \pm 1.46$ & $10.80 \pm 1.16$ & $10.20 \pm 2.00$ \\
\cline { 2 - 4 } & compared with restrained stress $($ RS $)$ control.
\end{tabular}

Table 5: Effect of Ocimum gratissimum on platelet count $\left(\times 10^{9} / \mathrm{L}\right)$ of Wistar rats under restrained stress

\begin{tabular}{llll}
\hline Groups & Day 0 & Day 7 & Day 14 \\
\cline { 2 - 5 } Normal Control & $131.67 \pm 9.09$ & $162.55 \pm 8.15$ & $128.33 \pm 9.03$ \\
RS Control & $121.67 \pm 8.42$ & $125.50 \pm 8.14$ & $125.00 \pm 7.48$ \\
RS+100 mg/kg & $137.67 \pm 8.13$ & $173.33 \pm 9.17^{* \#}$ & $125.50 \pm 9.40$ \\
RS+200 mg/kg & $133.67 \pm 6.07$ & $157.50 \pm 3.10^{* \#}$ & $133.33 \pm 7.07$ \\
RS+400 mg/kg & $118.67 \pm 4.31$ & $135.00 \pm 5.12$ & $130.50 \pm 3.95$ \\
RS+Vitamin C & $128.67 \pm 8.09$ & $173.35 \pm 5.15^{* \#}$ & $157.50 \pm 7.03^{* \#}$ \\
\hline
\end{tabular}

All values are expressed as mean \pm standard error of mean $($ SEM $) ;{ }^{*}=P<0.05$ when compared with normal control; ${ }^{*}=P<0.05$ when compared with restrained stress $(R S)$ control.

The present study evaluated the beneficial effect of ethanolic extract of Ocimum gratissimum (OG) on haematological parameters of adult female Wistar rats under restrained stress. Restrained stress is reported to alter the body homeostasis and contributes to cardiovascular pathologies (Black and Garbutt, 2002). It has the ability of interrupting the functions of neuroendocrine cells and releasing hormones of the hypothalamus (O'Connor et al., 2020). Consequently, hematological parameters have been proven as viable markers for the assessment of health in humans and animals and several studies have focused on hematological indices as an indicator for stress evaluation (Kandeepan, 2014; Kori et al., 2017, Pandian et al., 2018; Ueno et al., 2019; Bamidele et al., 2020). Results from our study recorded an increase in PCV and total RBC in the stressed groups. However, following administration with OG extract, we recorded a dose-dependent significant increase in $\mathrm{PCV}$ and total RBC compared to vitamin $\mathrm{C}$ that is a standard antioxidant. This implies that extract of $\mathrm{OG}$ alters stress-induced polycythemia and erythrocytosis and confirms that OG leaf extract is more potent in alleviating stress than vitamin $\mathrm{C}$. The decline might be linked to the antioxidative activity of OG through its total phenolic content (Ofem et al., 2012; Kori et al., 2017; Okechukwu et al., 2019). Reasons for this observation may be attributed to the fact that tissue anoxia causes the production of erythropoietin, which enhances erythrocyte production (Bowman et al., 2009). Consequently, Ebunlomo et al. (2012) demonstrated that stress induces a no significant change in RBC. White blood cell (WBC) counts are the first line indicators of immune response and they are the earliest blood cells to respond to immune modulating agents and stressors (Ebunlomo et al., 2012). We hypothesized that OG and vitamin $C$ may alter total WBC count of RS Wistar rats. In this study,
100,200 , and $400 \mathrm{mg} / \mathrm{kg} / \mathrm{bw}$ of $\mathrm{OC}$ and vitamin C were administered to restrained animals for 7 and 14 days. Our study demonstrated that stress elevates WBC counts. This increase in WBC is in tandem with a study by Bamidele et al. (2020) who reported that stress increases circulating WBCs in the blood but disagrees with that of Ramadan and Alshamrani (2015) who reported a decline in WBC of animals exposed to immobilized stress. During stress, the hypothalamus secretes stress hormones (corticotropinreleasing hormone) which acts on the pituitary gland to initiate regulated stress response pathway by activating the release of immune boosters such as WBC (O'Connor et al., 2020). More so, increase WBCs may be linked to increase beta-adrenergic binding during chronic stress (Abiramasudari et al., 2012). Interestingly, our study revealed that administration of OG extract to immobilized rats led to a decline in stress-induced increase in WBC compared to vitamin C. Although the exact mechanism of action of $\mathrm{OG}$ in reducing $\mathrm{WBC}$ in stressed animals is unknown, it is believed that plants with antioxidants reduce blood glucose by inhibiting the breakdown of glucose (Bamidele et al., 2020). Also, the reduction in WBC may also be a proof of the plants antibacterial activities as previously reported (Matasyoh et al., 2007; Omodamiro and Jimoh, 2015).

A significant dose-dependent increase in haemoglobin concentration in OG treated female RS rats was observed when compared to the normal control and stress control animal, thus indicating that $\mathrm{OG}$ increases the concentration of haemoglobin. The significant increase in hemoglobin concentration is linked to the various constituents of $\mathrm{OG}$ such as calcium, potassium, magnesium, phosphorous, iron, zinc, manganese, sodium, nickel, copper, and 
vitamins, which are necessary for the formation of blood cells (Asaolu et al., 2012).

Platelets play major functions in the maintenance of body milieu (Cognasse et al., 2019). Blood platelets, mediate inflammatory responses and functions in the effective clearance of pathogens (Cognasse et al., 2019). Our study demonstrated a significant decrease in platelet counts in restrained animals when compared to the control and experimental groups. One of the mechanisms behind this observation may be that stress is reported to activates the sympathetic part of the nervous system thus leading to an elevation of catecholamines, norepinephrine and epinephrine (Von Känel and Dimsdale, 2000; Brydon and Magid, 2006). Another study showed that epinephrine and norepinephrine enhance activation of blood platelet (Von Känel and Dimsdale, 2000) while Steptoe et al. (2003) linked platelet activation and stress-induced cardiovascular responses to the sympathetic nervous system. Our study revealed a significant increase in platelet count of the experimental animals following $\mathrm{OG}$ and vitamin $\mathrm{C}$ administration compared to the normal control and RS control groups. This result pattern disagrees with the findings by Ofem et al. (2012) who demonstrated that oral administration of OG to male albino rats led to decline in platelet indices although in their study experimental animals were not subjected to stress. This observation may be because of the interactions between the antioxidative properties of OG leaf and the $\alpha$-adrenergic receptors and $\alpha$-adrenergic receptors in surface of the platelet membranes or it could be that eugenol an essential oil of $\mathrm{OG}$ activates the production and expression of thrombopoietin. Even though the mechanisms of action of co-administration of $\mathrm{OG}$ on prolonged stress is unknown, our result findings indicated that oral administration of $\mathrm{OG}$ could relieve some hematological stress indices. This may be attributed to the antioxidative properties of OG (Okechukwu et al., 2019).

Conclusion: Our study showed that intake of Ocimum gratissimum is effective in alleviating prolonged stress. Ocimum gratissimum leaves extract demonstrated promising results in combating polycythemia, erythrocytosis, and thrombocytopenia induced by exposure to stress. Hence, consumption of Ocimum gratissimum leaves as part of human dietary supplement is advised.

\section{REFERENCES}

Abiramasundari, G; Sumalatha, KR; Sreepriya, M (2012). Effects of Tinospora cordifolia (Menispermaceae) on the proliferation, osteogenic differentiation and mineralization of osteoblast model systems in vitro. J. Ethnopharmacol. 141(1): 474-80.

Aguiyi, JC; Obi, CI; Gang, SS; Igweh, AC (2000). Hypoglycaemic activity of Ocimum gratissimum in rats. Fitoterapia. 71(4): 444-6.

Anachuna, KK; Oyem, CJ; Nwogueze, BC; Asiwe, JN (2018). Glucose lowering effects and histomorphological changes of Vernonia amygdalina on pancreatic compromised Wistar rats using alloxan monohydrate. Trop. J. Health Sci. 25(2): 27-31.

Asaolu, SS; Adefemi, OS; Oyakilome, IG; Ajibulu, KE; Asaolu, MF (2012). Proximate and mineral composition of Nigerian leafy vegetables. J. Food Res. 1(3): 214.

Ayinla, MT; Dada, SO; Shittu, ST; Olayaki, LA; Akiode, AO; Ojulari, SL (2011). Antihyperlipidemic effect of aqueous leaf extract of Ocimum gratissimum in alloxan induced diabetic rats. Int. J. Med. Med. Sci. 3(12): 360-3.

Bamidele, O; Chisom, N; Gabriel, T; Dayo, L; Moses, A (2020). Methanol extracts of Basella alba leaves alleviate stress in rats. Chin. Herb Med. 12(2): 163-170.

Bhattacharya, SK; Ghosal, S (2000). Experimental evaluation of the anti-stress activity of a herbal formulation, zetress. J. Nat. Remedies. 1: 1-7.

Birben, E; Sahiner, UM; Sackesen, C; Erzurum, S; Kalayci, O (2012). Oxidative stress and antioxidant defense. World Allergy Organ. J. 5(1): 9-19.

Black, PH; Garbutt, LD (2002). Stress, inflammation and cardiovascular disease. J. Psychosom. Res. 52(1): 1-23.

Bowman, M; Riddel, J; Rand, ML; Tosetto, A; Silva, M; James, PD (2009). Evaluation of the diagnostic utility for von Willebrand disease of a pediatric bleeding questionnaire. J. Thromb. Haemost. 7(8): 1418-21.

Brydon, L; Magid, K; Steptoe, A (2006). Platelets, coronary heart disease, and stress. Brain Behav. Immun. 20(2): 113-9.

Calabrese, EJ; Bachmann, KA; Bailer, AJ; Bolger, PM; Borak, J; Cai, L; et al (2007). Biological stress response terminology: Integrating the concepts of adaptive response and preconditioning stress within a hormetic dose-response framework. Toxicol. Appl. Pharmacol. 222(1): 122-8. 
Chao, P-Y; Lin, JA; Ting, W-J; Lee, H-H; Hsieh, K; Chiu, Y-W; et al (2016). Ocimum gratissmum aqueous extract reduces plasma lipid in hypercholesterol-fed hamsters. Int. J. Med. Sci. 13(11): 819-24.

Cognasse, F; Laradi, S; Berthelot, P; Bourlet, T; Marotte, H; Mismetti, P; Garraud, O; HamzehCognasse. H (2019). Platelet Inflammatory Response to Stress. Front Immunol. 10: 1478.

Ebunlomo, AO; Odetola, AO; Bamidele, O; Egwurugwu, JN; Maduka, S; Anopue, J (2012). Effects of Emilia praetermissa leaf extract on the haematological and biochemical parameters of stress induced ulcerated Wistar rats. African $J$. Biochem. Res. 6(14): 185-9.

Ekor M. "The growing use of herbal medicines: issues relating to adverse reactions and challenges in monitoring safety" Front Pharmacol, 4, 177.

Emudainohwo, JOT; Moke, EG; Erhirhie, EO (2015). Effect of Aqueous Extract of Unripe Seeds of Carica papaya on Four Hematological Parameters of Salmonella-Induce Enteric Fever in Wistar Rats. J Adv Med. Pharm. Sci. 4(2): 1-9.

Erhirhie, EO; Ben-Azu, B; Moke, EG; Chinwuba, P; Omonjiahio, IA (2015). Ethno-pharmacological Review of Buchhoizia coriacea (Wonderful Kola). IJAPBC. 4(1): 149-155

Gudipudi, S; Puranik, DS; Alla, R; Ajjarapu, U; Kistammagari, TR (2015). Anti-stress activity of Euphorbia thymifolia L. aqueous root extract in female rats. Int. J. Pharma Sci. Res. 6(4): 640-4.

Ijeh, I; Njoku, O; Ekenze, EC (2004). Medicinal evaluation of extracts of Xylopia aethiopica and Ocimum gratissium. J. Med. Aromat. Plant Sci. 26(1): 44-7.

Kandeepan, C (2014). Effect of Stress on Haematological Parameters of Air Breathing Loach Lepidocephalus thermalis (Cuv \& Val). Int. J. Curr. Res. Aca. Rev. 2(8): 309-22.

Kori, RS; Aladkatti, RH; Desai, SD; Das, KK (2017). Effect of Anti-stress Activity of Fluoxetine on Restrained Stress Induced Male Effect of Antistress Activity of Fluoxetine on Restrained Stress Induced Male Albino Rats in Hematological Parameters and Whole Brain Histopathology. $J$. Young. Pharm. 9(2): 246-250.
Ladokun, O; Ojezele, M; Arojojoye, O (2015). Comparative study on the effects of aqueous extracts of viscum album (mistletoe) from three host plants on hematological parameters in albino rats. Afr. Health Sci. 15(2): 606-12.

Matasyoh, LG; Matasyoh, JC; Wachira, FN; Kinyua, MG; Thairu Muigai, AW; Mukiama, TK. Chemical composition and antimicrobial activity of the essential oil of Ocimum gratissimum $\mathrm{L}$. growing in Eastern Kenya. African J. Biotechnol. 6(6): 760-5.

Moke, EG; Anachuna, KK; Edje, KE; Ojezele, MO (2019). Hepatoprotective effect of methanol seed extract of Citrus tangerina on paracetamol-induced hepatotoxicity in Wistar rats. Niger. J. Nat. Prod. Med. 23: 83-87.

Moke, EG; Oghoghovwe, I; Ahante, E (2018). The Effect of Omega ${ }^{\circledR}$ Roots + Ginseng Aloe Vera, a Nigerian Herbal Mixture, on Haematological Parameters of Normal Experimental Rats. J. Drug Deliv. Ther. 8(3): 29-31

Moke, EG; Umukoro, EK; Asiwe, JN; Omogbiya, AI; Erhirhie, EO; Ben-Azu, B; Anieh, FU (2021). Herbal Medicine: Education and Occupation Influences Its Practice among Residents of Port Harcourt, South-South Nigeria. Int. J. Pharm. Phytopharm. Res. 11(2): 38-44.

O’Connor, TM; O’Halloran, DJ; Shanahan, F (2000). The stress response and the hypothalamicpituitary-adrenal axis: from molecule to melancholia. QJM. 93(6): 323-33.

, O; Ani, E; Eno, A (2012). Effect of aqueous leaves extract of Ocimum gratissimum on hematological parameters in rats. Int. J Appl. Basic. Med Res. 2(1):38-42.

Okechukwu, GN; Ezor, E; Finbarrs-Bello, E; Ebube, LN; Uzomba, GC; Ibegbu, AO (2019). Effects of Aqueous Extract of Ocimum gratissimum Leaves and Vitamin $\mathrm{C}$ on Lead Acetate-induced Changes in the Thymus of Adult Wistar Rats. Int. J. Biochem. Res. Rev. 26(1): 1-9.

Omodamiro, OD; Jimoh, MA (2015). Antioxidant and antibacterial activities of Ocimum gratissimum. Am. J. Phytomed. Clin. Ther. 3(1): 10-19.

Pandian, M; Padmaja, RD; Ravindran R (2018). Effect of 4-Allyl-2- Methoxyphenol (Eugenol) On Red Blood Cells In Subacute Restraint Stress Induced 
Wistar Albino Rats. J. Dent. Med. Sci. 12(17): 8185.

Ramadan, KS; Alshamrani, SA (2015). Effects of Salvadora persica Extract on the Hematological and Biochemical Alterations against Immobilization-Induced Rats. Scientifica (Cairo). 2015: 253195.

Sarjan, HN; Divyashree, S; Yajurvedi, HN (2017). The protective effect of the Vacha rhizome extract on chronic stress-induced immunodeficiency in rat. Pharm Biol. 55(1): 1358-1367

Shittu, S-T; Oyeyemi, W; Lasisi, T; Shittu, S-S; Lawal, T; Olujobi, S (2016). Aqueous leaf extract of Ocimum gratissimum improves hematological parameters in alloxan-induced diabetic rats via its antioxidant properties. Int. J. Appl. Basic. Med. Res. 6(2): 96.

Steptoe, A; Magid, K; Edwards, S; Brydon, L; Hong, Y; Erusalimsky, J (2003). The influence of psychological stress and socioeconomic status on platelet activation in men. Atherosclerosis. 168(1): 57-63
Thrall, MA; Weiser, G; Allison, R; Campbell, T (2012). Veterinary hematology and clinical chemistry. John Wiley \& Sons.

Ueno, H; Shimada, A; Suemitsu, S; Murakami, S; Kitamura, N (2019). Anti-stress effects of the hydroalcoholic extract of Rosa gallica officinalis in mice. Heliyon. e01945.

Von Känel, R; Dimsdale, JE (2000). Effects of sympathetic activation by adrenergic infusions on hemostasis in vivo. Eur. J. Haematol. 65(6): 35769.

World Health Organisation (WHO) (2013). WHO Traditional Medicine Strategy 2014-2023. http://www.who.int/medicines/publications/traditi onal/trm_strategy14_23/en/ (accessed 12 June 2021)

Yaribeygi, H; Panahi, Y; Sahraei, H; Johnston, TP; Sahebkar, A (2017). The impact of stress on body function: A review. EXCLI J. 16: 1057-1072. 